\title{
Learning for sustainable futures: a human development approach to citizenship education
}

\section{Tendayi Marovah and Melanie Walker}

\begin{abstract}
Situated in debates on citizenship formation through higher education, this paper contributes to literature on policy processes and practices in the operationalisation of National and Strategic Studies, a citizenship education course in Zimbabwean teachers' colleges. This is in order to evaluate the extent to which these practices and processes support the principles of human development which are linked to sustainability. This paper argues that a human development approach focusing on four values: empowerment, participation, sustainability and equity is significant in reimagining policy processes and practices that contribute towards learning for sustainable futures. Drawing on interview data of two mid-level policy stakeholders, from a qualitative research study, the results indicate that policy processes undertaken in the introduction and operationalisation of National and Strategic Studies do not reflect and uphold democratic principles contributing towards human development, social justice and hence sustainability. The contested democratic space in the broader context of the course has a bearing on the policy processes and practises adopted by policy stakeholders.
\end{abstract}

\section{Introduction}

Education for sustainable futures has to be understood within the context of complex ecologies that involve historical, structural, political, environmental, and ethical dimensions. 'Human development' and 'sustainable learning' are current 'catch' phrases in education broadly, higher education and various other fields. Together with related concepts such as equity, for example, sustainability, tend to conceal the absence of precise meaning of what it means to educate citizens for critical democratic citizenship. When used as a catch word, the term sustainable learning loses much of its value in 
understanding the complexities of citizenship formation in higher education. As such, it is necessary to interrogate the notion of learning for sustainable futures, what it means, and why it is helpful in understanding citizenship formation in a higher education context. There is vast literature on critical democratic citizenship in education (McLaughlin, 1992; Ranger, 2004; Nyakudya, 2007, 2011; McCowan and Unterhalter, 2009, 2013; Boni and Gasper, 2012; Boni and Arias, 2013; Munikwa and Pedzisai, 2013), there is limited focus on policy practices and processes linked to sustainability. Thus, this conceptual and empirical paper provides a useful focus point for a discussion of policy processes and practice in relation to learning for sustainable futures.

The difference between the perceived meaning of sustainable learning, critical democratic citizenship and the ways in which this is translated into policy is one example of how competing critical citizenship claims play out in citizenship formation in higher education. Critical citizenship in this case is understood as the form of citizenship which allows active participation of citizens in the political affairs of their country (Nussbaum, 2002; 2006; McCowan and Unterhalter, 2009; 2013; Boni et al. 2010; Walker and Loots, 2016). This way, citizenship education is so important to today's conflicting world. As suggested by UNESCO (2001, p.1) making reference to the ultimate goal of education for sustainable development, citizenship education should seek "to empower people with the perspectives, knowledge, and skills for helping them live in peaceful sustainable societies". From this claim, this paper argues against processes and practices that avoid active participation of citizens in programmes which affect them.

The paper is divided into five sections which start with a conceptualisation of sustainability followed by a brief discussion of underlying four human development values as applied to education. The values are equity, participation, empowerment and sustainability. The third section provides an overview of the study methodology. Thereafter, the paper presents empirical data demonstrating how policy stakeholders experience the operationalisation of National and Strategic Studies. The last section encompasses a synthesis of policy processes and practices showing how the human development framework provides a helpful lens for interpreting the various complexities and contradictions that emerge from the data, and so potentially opens up new avenues for interventions that seek to advance learning for sustainable futures. In the next section, the paper conceptualises sustainability, learning for sustainable futures and how these relate to citizenship education. 


\section{Conceptualisation of sustainability}

More than three decades after the World Commission on Environment and Development (WCED) (UN, 1987) defined 'sustainable development' and put the concept of sustainability on the global agenda, the concrete meaning of this term and its suitability for specific cases remains disputed. As noted by Marovah (2013) sustainability is usually seen as a guide for economic and social policy making in equilibrium with ecological conditions. It is with this understanding that concepts around sustainability - including sustainable learning are interrogated. Sustainable learning - takes its cue from millennium development goals that were later translated into sustainable development goals. Stallmann (2010) suggests that sustainability should be understood as more expansive and multi-layered. As such it is applicable in many areas such as development, environment, education and policy formulation. This paper thus relates sustainability to education with a focus on advancing human development, providing access to justice for all and building effective and accountable institutions leading to the promotion of peaceful and inclusive societies.

Learning for sustainable futures is thus understood as learning that seeks to 'meet the needs of the present without compromising the ability of future generations to meet their own needs' (UN, 1987, p.8). Drawing on the human development framework, sustainability is considered as a moral obligation necessary for the advancement of democracy and social justice (United Nations Development Programme (UNDP), 1990). In this light, the potential role of citizenship education in advancing human development and the deepening and strengthening of democratic values cannot be underestimated. This means, citizenship should be about empowered citizens who enjoy substantive freedom and equal opportunities to actively participate in decision-making processes in their polity. At the same time, active participation increases citizens' confidence and participation in conventional political processes, enhancing citizens' sense of belonging in society, ensuring respect for the law, and fulfilling citizens' duties towards the state (McCowan and Unterhalter, 2013). From a citizenship education dimension, learning for sustainable future should be framed as more than learning about knowledge and principles related to sustainability (UNESCO, 2012). In other words, it should be transformative in its broadest sense, with creating more sustainable societies as its central goal. 
This paper thus asserts that to achieve learning for a sustainable future, citizenship education should be hinged on "problem-based and exploratory forms of learning" grounded on critical, creative and change-oriented participation (UNESCO, 2012, p.5). Based on this assertion, the creation of stronger, healthier and more equitable communities is central to learning for sustainability, making it imperative to focus on policy processes and practices towards this end. The next section discusses the role of four human development values in advancing policy processes and practice linked to sustainability and learning for sustainable futures.

\section{Human development values}

At the heart of the human development framework are four principles, participation, equity, sustainability and empowerment, which this paper considers as linked to learning for sustainable future. The principles are in tandem with UNESCO's (2012, p.10) multifaceted approach to sustainability focusing on areas such as "ecological, environmental, economic and socio-cultural; local, regional and global; past, present and future; human and non-human". The four human development principles also question predominant approaches to policy practice which may turn out to be unsustainable for example the top down approach used in the operationalisation of citizenship education in Zimbabwe. Through the principle of empowerment the paper advances a transformative approach to sustainability, moving beyond awareness to incorporate real change to values and policy practices in citizenship education. The principle of equity demands a context specific model of engaging citizens simultaneously acknowledging that "there is no one way of living, valuing and doing business that is most sustainable" (UNESCO, 2012, p.10). In the same manner, the level of participation is not homogeneous for all citizens in different contexts, but is determined by contexts and individual attributes. From this understanding, defining human development as "creating an environment in which [citizens] can develop their full potential and lead productive and creative lives in accord with their needs and interests" advances sustainability (UNDP, 1990, p.1). Therefore, sustainable human development should not be measured by how much material gain or profit is achieved in the process of human activity, but rather by how much value has been added towards improving citizens' potentials, choices or freedoms to be or to do what they perceive as valuable. However this does not mean that economic considerations should be 
neglected (Walker, 2012). Rather, the point as argued by Sen (1999) is that, a country's Gross Domestic Product does not tell us how the wealth so gained is distributed across the population, nor does it give insights into the quality of growth achieved.

Drawing on the interconnected human development values: empowerment, participation, equity and sustainability, curriculum innovations at higher education level should endeavour to put people at the centre. Not only viewed as skilled manpower, but as the wealth of the nation, and as individuals of moral worth, and not the means of development (including educational development). Alkire (2010) and Ibrahim (2014) explain that empowerment as envisaged in human development entails ensuring that people are capacitated to make choices and to transform those choices into desired actions and outcomes. Participation gives space to individuals and groups to be actively and meaningfully involved in the formulation, implementation and monitoring of policy and curriculum as well as pedagogical processes and practices. The participation of citizens including youth/students ensures that decisions made and opportunities created do not jeopardise the choices and opportunities of future generations. Equity on the other hand guarantees equality, fairness and social justice so that whatever processes and practices are undertaken uphold these guarantees across different dimensions like gender, age, political affiliation and many others. Sen (1999) argues that human development is concerned with the basic development idea of advancing the richness of human life rather than the economy in which human beings live, which is only part of it. This resonates with ul Haq's notion: "The basic purpose of development is to enlarge people's choices. In principle, these choices can be infinite and can change over time" (UNDP, 1990, p.10). Since people also value achievements that may be unattainable or not necessarily measurable in income or growth figures, such as greater access to knowledge, better nutrition and health services, and a sense of participation in community activities, the objective of development in ul Haq's words "is to create an enabling environment for people to enjoy long, healthy and creative lives" (UNDP, 1990, p1). This vision of enlarging citizens' choices and freedoms to pursue what they value to be or to do is in line with learning for sustainable futures understood as meeting the needs of the present without compromising the ability of future generations to meet their own needs.

The emphasis on choices and empowerment, which other studies on National and Strategic Studies seem not to emphasise, offers a better perspective for 
the formation of critical democratic citizens (Ranger, 2004; Tendi, 2010; Nyakudya, 2007, 2011; Mavhunga, Moyo and Chinyani, 2007, Munikwa and Pedzisai, 2013). Closely connected to the process of enhancing the capacity of individuals or groups to make choices in order to transform those choices into desired actions and outcomes, is participation. Participation, a process through which all members of a community or organization are involved and have influence on decisions related to development activities that will affect them, is feasible where citizens are empowered. In other words it is not enough to have representation which is voiceless or powerless (Fraser, 2009). In the same way, to decide by consensus where there is no equitable distribution of power among citizens concerned is a subtle way of perpetuating injustice and is thus unsustainable. In this case, the human development values under discussion add value to citizenship formation by emphasising empowerment, participation, equity and sustainability. Equity extends the notion of the interconnectedness of humanity by enabling the accommodation of marginalised and oppressed minority groups within society. In addition, equity is a way of managing society in a sustainable way since the ability or capacity of something to be maintained or to sustain itself is based on the level of participation, empowerment and distribution of power and resources. A framework which is silent on these values defeats the course of sustainable learning and the formation of critical democratic citizens.

Turning to its limitations, the human development framework fails to adequately capture institutional and structural arrangements which may enhance or inhibit the realisation of the four values explained above. For example, in the Zimbabwean context, whilst advocating for citizens to participate in activities affecting them in their state, citizenship education offers limited discussion on how to deal with structures of power which inhibit participation (Ranger, 2004; Tendi, 2010). Yet, the human development values' effectiveness in fostering critical citizenship is dependent on the existence of a reciprocal relationship between democratic politics and democratic education. Walker (2010, p.221) argues that "higher education is located within society and social change; changes in higher education might influence society as much as society in turn shapes higher education". Accordingly, a democratic system of education is indispensable to further democratic citizenship, in as much as democratic citizenship is crucial for democratic education. Although this assumption is normative, it is necessary as a standard towards which we should work. 
In the next section the paper discusses the methodology chosen for the investigation of the extent to which National and Strategic Studies advances human development values.

\section{Methodology}

Without losing a firm theoretical base influenced by a human development framework, this section outlines the rationale and decisions taken regarding the design, the sample, data collection, organisation and analysis. The process and procedures were iterative, complex and ever-changing throughout the study.

This paper draws on empirical data from a doctoral study, collected between February and May 2013. The study was qualitative and interpretive in nature. The aim was to generate an in-depth understanding of practice and processes in the operationalisation of NASS in two case studies. While surveys are effective in providing statistical relations between selected variables, they are less effective where an in-depth understanding of perceptions of and attitudes towards a phenomenon are required. Thus a case study was preferred despite criticisms levelled against it, in terms of lack of generalisability, because it is more context-specific, and therefore important to understanding a phenomenon in its specific situation (Gall, Gall and Borg, 2003).

Despite the first author's positionality as both a lecturer in National and Strategic Studies and a researcher, the analysis of data was guided by both the particularity of the moment and a genuine commitment to advancing the formation of critical citizens contributing to human development and upholding social justice. He joined the college ten years after the introduction of National and Strategic Studies in teacher education. At each level of this empirical research: the planning, collection of data in situ and its analysis, philosophical, historical and educational approaches complemented each other by providing: a clear conceptual understanding of issues; the spirit of questioning; and consciousness of the context in which the formation of critical democratic citizens takes place.

The study involved 31 volunteer participants, two mid-level policy stakeholders, 24 student participants and five lecturers from two participating primary school teacher colleges. The doctoral study made use of qualitative 
methods that include semi structured in-depth interviews of all the 31 participants, focus group discussions with student participants, class observations and document analysis. Participants' names are anonymised in line with ethical considerations.

The focus is on evidence from two mid-level stakeholders, Simboti and Madamombe. Simboti was purposively chosen by virtue of his post at head office of the Ministry Of Higher and Tertiary Education Science and Technology Development under which teachers' colleges are administered. Madamombe, selected through snowballing, is from the University of Zimbabwe which grants associateship status to all teachers' colleges scattered throughout the country. Simboti and Madamombe were interviewed at their respective work places after getting approval from the Ministry Of Higher and Tertiary Education Science and Technology Development. The interviews were on average one hour long each. Their experiences are interpreted from a policy perspective. While Simboti is stationed in Harare, he constantly visits and holds meetings with college Principals for various purposes including quality control. Madamombe is a lecturer in one of the departments at the University of Zimbabwe but is engaged in several duties related to teacher education including external examination and academic writing in the Department of Teacher Education. The fact that there are only two mid-level policy stakeholder views represented in the broad study and in this paper is acknowledged as a limitation since their views are not necessarily representative of all who were involved in National and Strategic Studies' implementation. However, this does not undermine the invaluable insights gleaned from their experiences.

With the help of the second author, who was the supervisor in the study, the qualitative data was analysed using NVivo software. All qualitative data was open-coded initially to allow participant voices to emerge and guide the identification of themes. Thereafter, a second round of thematic coding was also done. The paper focuses on one of the emergent themes -policy practices and processes. The iterative process involving two authors of different backgrounds, enhanced rigour simultaneously limiting subjectivity in the analysis and interpretation of the data.

In the next section, the article reflects on the conditions of possibility for advancing policy practices contributing to human development and learning for a sustainable future using human development values to guide the argument. 


\section{The context of the introduction of NASS}

By discussing the context, the aim is to understand the degree to which the context provides a good grounding for advancing critical citizenship which is directly linked to sustainable learning. This is because critical citizenship entails forming citizens who are empowered to actively participate in the affairs of their polity (McCowan and Unterhalter, 2009, 2013; Fraser, 2009). Four developments relate to the context: the introduction of draconian laws like the Public Order Security Act ${ }^{1}$ and the Access to Information and Protection of Privacy Amendment Act, ${ }^{2}$ the redefinition of citizenship in an exclusionary manner, the introduction of National Youth Service ${ }^{3}$ and the revision of the national curriculum (Phimister, 2005; Raftopoulos, 2009; Daimon, 2014). The increased use of executive powers by the president became an important lever through which a directive to introduce citizenship education in tertiary institutions was made using well placed officials. ${ }^{4}$ In such a context, it is doubtful whether it is possible to teach or learn citizenship for sustainable futures. The interests advanced in this context of limited citizens' participation, are of those in power.

The critical voice provides an opportunity for the citizens to demand their space by challenging structures of power which are repressive. The two informants views about the context in which National and Strategic Studies

Passed in 2002 and restricted freedom of assembly; to criticise the government and President; and to engage in, advocate or organise acts of peaceful civil disobedience.

Restricted the culture of secrecy prevalent in most democratic systems it suggests that access to information is not seen as a right but a privilege that government officials dispense at will, Read more on http://www.freedominfo.org/2012/08/report-excoriates-zimbabwe-access-environment/

National Youth Service was introduced in July 2001 focusing on instilling youth with the following five values: National Identity, Patriotism, Unity and Oneness, Discipline and Self Reliance. Participants spend three months in training camps, after which they are required to complete a one month service project in their communities. (See Ministry of Youth Development: http://www.mydgec.gov.zw/nys.htm) 
was introduced, though at times contrasting, provides insights on the level of participation of citizens. Although Simboti was not explicit on why he was not comfortable with discussing the context, some of his responses provide some hints, "These political arguments do not get us anywhere and this is exactly what made people to resist this course from the beginning." From his statement it is clear that he regards discussing the context as a political issue and that during the initial stages of the introduction of National and Strategic Studies, the course was resisted because those who resisted thought the course was political. However, Simboti does not deny or accept the allegations that the course was introduced for political expedience specifically to buttress ZANU PF support which was waning "So whether the government was beleaguered or not, the idea of coming up with a person who is broad minded is very noble".

He however admits that the context influences the policy processes and operationalisation of a curriculum innovation.

How these things [policy processes] work depend on a number of things including how the economy is performing, the social and the political situation. We have a lot of polarisation to the extent that we cannot claim that the people who are teaching National and Strategic Studies are perfect people.

Simboti does not mention any relationship between the introduction of National and Strategic Studies and the Commission of Inquiry into Education and Training (1999), which, if it was important, as a mid-level policy stakeholder he would have known. Apart from that he does not cite any policy document communicating details of the government's decision to introduce National and Strategic Studies. This as suggested by Sigauke (2011) means the decision to introduce National and Strategic Studies was influenced by political motives not necessarily related to policy.

Turning now to Madamombe's thicker and more critical responses when compared to Simboti's, he explains:

There are two different issues that are emerging here, what was intended by those who pushed for it and what then obtained on the ground. I am saying those who came up with the programme are coming from a position where they are saying there are so many forces that are against 'us' but us not being the nation of Zimbabwe but us referring to 
a political party. There was need to help inculcate within graduates from learning institutions a certain kind of thinking. What I commend them for doing is that when we crafted the syllabus for National and Strategic Studies in the teachers' colleges we were not influenced by our political orientations, perhaps that justifies the kind of question that you are pursuing that is this perceived or real.

The way Madamombe separates issues into various dimensions helps us understand different possibilities motivating the introduction of National and Strategic Studies. At one level are the intended outcomes for the state, which are represented by the mid-level policy stakeholder participants and at implementation level we get insights on what obtained in practice from the lecturer participants and the student participants. Which means, the intended goals and what then obtained is different. The disjuncture between official precepts and its practices also emerged in McCowan's (2009) study on citizenship education involving Brazilian cases. A number of factors contribute to these disparities. These nuances help us understand why Simboti, a senior official at head office, has been hesitant to discuss the context. He has to be interpreted as trying to be politically 'correct'. Madamombe further suggests that the Department Of Teacher Education is free from manipulation by political influences. This claim cannot be ascertained in this paper, however. The issue at stake is whether the processes uphold human development values related to advancing learning for a sustainable future.

Madamombe provides more insights in the following statements with more emphasis on the fact that our understanding of the context should not overshadow the necessity of the course:

But then there are other angles that we can look at it from, where you ask yourself, at what stage was National And Strategic Studies introduced? This is when the ruling party is beleaguered when it starts to face real stiff competition, opposition if you want. Then you link this up with other developments where the Border Gezi programmes, National Youth Service is introduced.

Directly linked to the introduction of National and Strategic Studies was growing opposition (Ranger, 2004; Tendi, 2010) and also the introduction of National Youth Service which Madamombe claims 
generated suspicion about National and Strategic Studies. He adds that the context was so 'poisoned' that the teaching of the course was somehow dictated by the politics of the day. To him the timing is quite influential through either giving impetus to the innovation or destabilising it. Nonetheless, Simboti and Madamombe agree on the significance of the new course despite its timing or context.

Madamombe illustrates how fear infected the context in which, for example, History ${ }^{5}$ was taught at various levels of education.

Yes a lot of fear is experienced and we have a lot of empirical evidence of teachers of history in particular who have been abused mainly in the rural areas for instance and they will shy away from looking at these issues critically. The history syllabus extends to the present and the majority of the teachers are teaching it up to 1980, I am talking about $O$ level and A level history syllabus on Zimbabwe because of fear of tackling the post-independence era because they realised that it's not all rosy that they will be teaching, there is a lot of negatives a lot of 'warts' that they have to point out and they will not resonate well with certain sections of our society. Even where people have not been approached and told don't teach this, there is self-censorship. That self-censorship is not mere cowardice which cannot be understood. It is understood there has been a lot of violence against these people. People have lost limbs, people have lost lives because of this, that's my own opinion.

On the other hand Simboti claims not to be aware of the existence of fear "fear of what? There is no need to fear, there is no need to be afraid of anything". What is surprising is how Simboti and Madamombe claim that National and Strategic Studies seeks to form critical citizens. If Madamombe was genuinely concerned about the advancement of critical citizenship, he would realise how difficult it is to teach for criticality in the context of fear, just as he noted in the teaching of History.

National and Strategic Studies has a component of History which has been named Patriotic History by scholars such as Ranger (2004, p.215) “'Patriotic history' is intended to proclaim the continuity of the Zimbabwean revolutionary tradition. It is an attempt to reach out to 'youth' over the heads of their parents and teachers, all of whom are said to have forgotten or betrayed revolutionary values. It repudiates academic historiography with its attempts to complicate and question. At the same time, it confronts Western 'bogus universalism' which it depicts as a denial of the concrete history of global oppression. 
This section presented evidence on mid-level policy stakeholder participants' perspectives on the interpretation of the relationship between the context in Zimbabwe and the introduction of National and Strategic Studies. While Simboti chose not to say much about how the context influenced the introduction of this curriculum innovation, Madamombe sees the political side of the introduction of National and Strategic Studies as a response to growing opposition. To him, as suggested by several critics of citizenship education in Zimbabwe, it was the desire for political survival by the ruling elites which influenced this innovation (Ranger, 2004; Tendi, 2010; Sigauke, 2011). He sees the fear of the government's brutality extended to the citizens through various coping strategies in education and society including self-censorship. As a senior official in the Ministry Of Higher and Tertiary Education Science and Technology Development, Simboti seeks to maintain the official position and focuses on implementing what is handed down to him by government without questioning. Basing on the importance placed on citizenship participation by Sen (1999); McCowan and Unterhalter (2009; 2013) and Sigauke, (2011), the context in which National and Strategic Studies was introduced does not provide a secure grounding for the formation of critical citizenship. In addition the context does not offer a good foundation for effective participation by various stakeholders in deliberations leading to the introduction of National and Strategic Studies. In the next section the paper uses four human development values, directly linked to sustainability, to evaluate policy processes regarding the introduction of National and Strategic Studies.

\section{Evaluation of policy processes and practices}

The following evidence relates to perceptions linked to policy processes and practices. What is striking in the evidence is the absence of any policy document to back claims by the respondents. There was a passing reference to Commission of Inquiry into Education and Training by Simboti but not as a fore runner of the introduction of citizenship education or National and Strategic Studies in particular. What Simboti first acknowledges is that the strategy used to introduce this curriculum innovation was a top down approach: "Well it looks like we used the top down approach it did not come from the bottom. Its government which saw it fit to have it introduced." When asked why that approach in particular and not any other more open and people centred approach was adopted, he said "we are mainly people who follow 
policy, if government says this must be done, that is what we do". Considering that there is a blurred distinction between party and government as explained by Raftopoulos (2013), the party ideologies are filtered into the National and Strategic Studies curriculum. The approach does not provide participants with transformative power, which is the ability to challenge the hierarchies of power which inhibit effective participation of citizens in policy practices and processes (Fraser, 2009, UNESCO, 2012).

Simboti is suggesting that at their level there is no room for questioning instructions. This is also instructive of the modus operandi of the policy processes. In his words, without any questioning, the instruction went down the chain of command, "So the strategy which we used was that we told Department Of Teacher Education that this course is compulsory and every student has to pass National and Strategic Studies in order to graduate". More precisely, against the spirit of effective participation and equitable distribution of power and influence (McCowan and Unterhalter, 2009; Boni and Gasper, 2012; Boni and Arias, 2013), Simboti notes that "'. Simboti cites a few cases where officials met in regional workshops to claim that other stakeholders were involved "it's not something that had been done or is done single handedly". This does not mean that there was open deliberation for the innovation to be taken aboard. For example Simboti tells us that:

First we had workshops in Nyanga, then the other one in Gweru, another one in Kadoma and then another in Masvingo where we invited all Principals, and Lecturers in that course to an extent that I think that assisted in informing various stakeholders that the course was there to stay.

Whilst workshops can be participatory and a more open and a democratic way of introducing a curriculum innovation, in the above case, they are also a subtle way of coercion in which participants are informed of what has to be done without inviting any criticism. From Simboti's response, the purpose of the workshop "was to inform stakeholders that the course was there to stay". Those outside the system may wrongly believe that the innovation was discussed and well received.

Simboti tells us about the magnitude of the resistance which was experienced when National and Strategic Studies was introduced: 
Of course even in teachers' colleges there was some resistance when we started, very stiff resistance. It was quite difficult, we introduced a course which even lecturers themselves were not comfortable with, and even the college administrators were not very comfortable with it. At first it was not given much time and importance on the college timetables.

Besides highlighting the level of resistance, this response also tells us how college administrators and lecturers exercised their agency in negotiating space. The manner in which this resistance was dealt with also tells a story, "There were some problems; we even punished some of the Principals for that" (Simboti). In turn administrators' decision to deploy lecturers perceived as 'problem lecturers ${ }^{6}$ to teach National and Strategic Studies also indicates that the course was not well received or taken seriously. Instituting punitive measures is an indicator that for the authorities, coercion worked better for them in place of deliberations. For this reason, the paper concurs with Nussbaum (2011, p133) that "it is bad to treat [human beings] like objects, pushing them without their consent". For example, workshops organised for principals and lecturers were meant to give directives to participants rather than to provide an opportunity for deliberation. In such a case, lack of equitable distribution of power makes the workshops merely symbolic and perfunctory.

Given this evidence, the paper proposes that the human development values are a potential vehicle for a genuine devolution of power and decision making in policy processes that strengthens claims to people-focused citizenship curriculum. McCowan and Unterhalter (2009) remind us that education is not only charged with values but also promotes the same values. One of the values advanced is empowerment. Considering the top down approach used by the Ministry Of Higher and Tertiary Education Science and Technology Development as reported by Simboti, the introduction of National and Strategic Studies in teachers' colleges did not meet this basic value. It is not surprising that under such circumstances the course experienced resistance.

UNDP (1993) underscores the intrinsic value of participation by both individuals and groups as a way of widening access to decision and power. Participation by citizens in their society has intrinsic value since it buttresses 
democracy. The limited participatory nature in the policy processes and practice in this regard directly affects equity which is interconnected to the distribution of citizens' basic capabilities that is freedoms, choices and opportunities to decide on the type of citizenship course to be undertaken. Thus, power was not evenly distributed to fully account for the principle of equity in the human development framework. Subtly, authorities remained in control of both the policy processes and the content of the course. This is not surprising as Simboti has already hinted that "it was take it or leave. Its either you agree with what we want to do or you are out". These words depict an inequitable distribution of power. Where equity is envisaged, we would expect collaboration not merely consultations where subordinates would be effectively involved not as mere recipients of instructions. This brings us to the last strand of values for our consideration, sustainability of the opportunities and choices that participants have to say, do and be what they value.

From the UNDP $(1993,1994)$ definitions of sustainability, policy processes and practice that meets sustainability should not be geared towards establishing a transitory state of affairs. Instead, they should aim to "sustain positive outcomes over time" at individual, group or national level (Alkire, 2010, p.19). Because of the urge to maintain power and influence, this does not come naturally in the policy processes; there must be a deliberate effort to remove barriers that sustain oppressive policy practices and structural injustices. Alkire (2010, p.19), argues that "decision makers need to know not only who is deprived but also who is chronically deprived" and to what extent. She adds that policy processes and practice must include "support for local initiatives that mitigate vulnerability, expand capabilities and sustain these expansions". To achieve this, the interconnectedness of the four human development values should be recognised and exercised. Without citizens' empowerment, there is no active participation and the equitable distribution of power will be diminished and ultimately the legacy that is left will derail continual growth which can be referred to as sustainable.

In the context of limited democratic space (explained earlier in the paper) in which National and Strategic Studies was introduced in Zimbabwean teachers' colleges, it can be argued that policy processes and practices for the introduction and operationalisation of National and Strategic Studies defeats the purpose of learning for sustainable futures. The following factors are notably constraining to this cause: the context of fear, the use of a top down approach with its dictatorial tendencies, limited deliberative space in 
'consultative' workshops, as well as punitive measures for dissenting voices. Punishment is hardly a good start to make lecturers teach National and Strategic Studies. In this regard, policy processes and practice in the National and Strategic Studies curriculum uses a minimalist approach. Framing policy processes and practice within a human development framework may go a long way in promoting learning for sustainable futures in National and Strategic studies and more broadly.

\section{Conclusion}

The paper has conceptualised sustainability as a basis for defining learning for sustainable futures simultaneously linking this to citizenship education. It advanced the human development framework focusing on underlying four values as useful for assessing policy processes and practice in the introduction and operationalisation of National and Strategic Studies in Zimbabwean teachers colleges. The values are equity, participation, empowerment and sustainability. It also provided a snapshot of the study methodology in order to validate the power of evidence provided in support of the paper's argument. The paper then presented empirical data demonstrating how policy stakeholders experienced the introduction and operationalisation of National and Strategic Studies in a constricted democratic space. In the last section the paper provides a synthesis of policy processes and practices showing how the four human development values provides a helpful lens for interpreting the various complexities and contradictions that emerged from the data.

\section{References}

Alkire, S. 2010. Human development: definitions, critiques, and related concepts in Human Development Research Paper, 2010/01, UNDP.

Boni, A. and Arias, B. 2013. 'People first: rethinking educational policies in times of crisis using the capability approach', Learning for Democracy, Vol.3, pp.797-815. 
Boni, A. and Gasper, D. 2012 'Rethinking the quality of universities: how can the human Development thinking contribute?' Journal of Human Development and Capabilities, 13(3): pp.451-470.

Boni, A., Perisa, J., Huesoa, A., Rodillaa, J.M. and Lozano, J.F. 2010. 'Capabilities for a cosmopolitan citizenship in higher education: the experience of the Technical University of Valencia', Procedia Social and Behavioural Sciences, 9: pp.1998-2002 and pp.451-470.

Commission of Inquiry into Education and Training. 1999. Report on the Zimbabwe Presidential Commission of Inquiry into Education and Training, Harare, Government Printers.

Daimon, A. 2014. Politics of 'othering' and the struggle for citizenship in independent Zimbabwe: voices from Malawian descendants. Africa Insight, 44(1): pp.136-150.

Fraser, N. 2009. Scales of justice: reimagining political space in a globalising world. New York: Columbia University Press.

Gall, M.D., Gall, J.P. and Borg, W.R. 2003. Educational research: an introduction (7th edition), Boston: Pearson Education.

Ibrahim, S. 2014 The capability approach: from theory to practice - rationale, review and reflections. In Ibrahim, S. and Tiwari, M. Eeds), The capability approach: from theory to practice. London: Palgrave Macmillan, pp.1-28.

Mavhunga, P.J., Moyo, N. and Chinyani, H. 2012. Towards a citizenship education for Zimbabwe. Zimbabwe Journal of Educational Research, 24(1): pp.47-60.

Marovah, T. 2013. Citizenship education and human capabilities: lynchpin for sustainable learning environment and social justice. The Journal for Transdisciplinary Research in Southern Africa, 9(3): Special edition, December 2013, pp.593-607.

McCowan,T. and Unterhalter, E. 2009. Education for democratic citizenship: a capabilities perspective. Background paper to the Brazil Human Development Report 2009. 
McCowan T. and Unterhalter, E. 2013. 'Education, citizenship and deliberative democracy: Sen's capability perspective'. In Hedtke, R. and Zimenkova, T. (Eds), Education for civic and political participation: a critical approach, New York: Taylor \& Francis, pp.135-154.

McLaughlin, T. 1992. Citizenship, diversity and education: a philosophical perspective. Journal of Moral Education, 21(3): pp.235-250.

Munikwa, S. and Pedzisai, C. 2013. Perceptions of in-service teachers on learning/teaching of citizenship education: a case study of Chinhoyi University of Technology, Mashonaland West Province, Zimbabwe. International Journal of Humanities and Social Science, 3(14): pp.121-129.

Nussbaum, M. 2002 'Education for citizenship in an era of global connection'. Studies in Philosophy and Education, 21: pp.289-303.

Nussbaum, M. 2006. 'Education and democratic citizenship: capabilities and quality education'. Journal of Human Development, 7(3): pp.385-395.

Nussbaum, M. 2011. Teaching Patriotism: Love and Critical Freedom: For a conference on Understanding Education in the United States: Its Legal and Social Implications, University of Chicago Law School, June 17-18, 2011.

Nyakudya, M. 2007. The rationale for national and strategic studies in teacher training colleges: fostering a sense of patriotism in trainee teachers. Zimbabwe Journal of Educational Research, 19(2): pp.115-126.

Nyakudya, M. 2011. Interactive teaching methods in national and strategic studies in teacher training colleges: defeating the myopia of patriotic history and political expediency. Zimbabwe Journal of Educational Research, 23(1): pp.26-43.

Phimister, I. 2005. 'Rambai Makashinga (Continue to Endure)': Zimbabwe's unending crisis. South African Historical Journal, 54(1): pp.112-126.

Raftopoulos, B. 2009. The crisis in Zimbabwe, 1998-2008. In Raftopoulos, B. and Mlambo, A. (Eds). A history from the pre-colonial period to 2008: becoming Zimbabwe. Harare: Weaver Press. 
Raftopoulos, B. (Ed.). 2013. The hard road to reform: the politics of Zimbabwe's global political agreement, Harare, Weaver Press.

Ranger, T. 2004. Nationalist historiography, patriotic history and the history of the nation: the struggle for the past in Zimbabwe. Journal of Southern African Studies, 30(2): pp.215-234.

Sen, A. 1999. Development as freedom. Oxford: Oxford University Press.

Sigauke, A.T. 2011. Citizenship and citizenship education: a critical discourse analysis of the Zimbabwe. Education Citizenship and Social Justice, 6(69): pp.69-86.

Stallmann, M. 2010. Sustainable learning environments: the issues and potential policy responses. Unpublished Master's dissertation. New Zealand: Lincoln University.

Tendi, B.M. 2010. An analysis of becoming Zimbabwe.

http://www.weaverpresszimbabwe.com/latest-reviews/59-becomingZimbabw e/317-review-of-becoming-zimbabwe-tendai-rtp.html. Accessed 04 October 2010.

United Nations . 1987. Brundtland Report of the World Commission on Environment and Development. New York: United Nations.

United Nations Development Programme. 1990. Human Development Report http://www.undp.org.zw/accessed on23/03/2012.

United Nations Development Programme. 1993. Human Development Report http://www.undp.orgaccessed 23/03/2012.

United Nations Development Programme. 1994. Human Development Report http://www.undp.org accessed 23/03/2012.

UNESCO. 2001. The Luneburg Declaration on Higher Education for Sustainable Development.

http://portal.unesco.org/education/en/file_download.php/a5bdee5aa9f89937b 3e55a0157e195e6LuneburgDeclaration.pdf. Accessed 23/08/2016. 
UNESCO. 2012. United Nations Decade of Education for Sustainable Development (2005-2014), Shaping the Education of Tomorrow, 2012 Full-length Report on the UN Decade of Education for Sustainable Development. Paris: UNESCO.

https://www.cbd.int/financial/mainstream/unesco-report2012.pdf . Accessed 22/08/2016.

Walker, M. 2010. 'Pedagogy for rich Human beingness in global times'. In Unterhalter, E. and Carpentier, V. (Eds), Global inequalities and higher education: whose interests are we serving? Hampshire: Palgrave McMillian.

Walker, M. 2012. 'A capital or capabilities education narrative in a world of staggering inequalities?'International Journal of Educational Development, 32: pp.384-393.

Walker. M. and Loots, S. 2016. 'Social citizenship formation at university: a South African case study'. Compare: A Journal of Comparative and International Education, pp.1-21. DOI:10.1080/03057925.2014.884920

Tendayi Marovah

University of the Free State

marovaht@gmail.com

Melanie Walker

University of the Free State

walkerj@ufs.ac.za

Melanie2walker@gmail.com 
